Simposium I Jaringan Perguruan Tinggi untuk Pembangunan Infrastruktur Indonesia, 2016

\title{
Taxiway Pavement Evaluation to Support the Operational of Terminal 2 Juanda Airport
}

\author{
Istiar $^{\mathrm{a} *}$, Indrasurya B. Mochtar ${ }^{\mathrm{b}}$, Wahju Herijanto ${ }^{\mathrm{a},}$ Catur Arif Prastyanto ${ }^{\mathrm{a}}$ \\ ${ }^{a}$ Institut Teknologi Sepuluh Nopember, Kampus ITS Sukolilo Jl. Arif Rahman Hakim, Surabaya 60111, Indonesia
}

\begin{abstract}
The movement of aircraft and passengers at Juanda international airport was increasing each year. Juanda airport airside infrastructure was almost reaching the maximum capacity. So that, PT. Angkasa Pura I as the operator of Juanda airport planned to revitalize the Juanda airport terminal that located on the south side. This terminal was not already 8 years operating. The infrastructure to be evaluated was the strength of taxiway pavement.
\end{abstract}

Juanda airport taxiway pavement evaluated by using software COMFAA. Data input into the software COMFAA was the existing pavement structure and movement of the aircraft that will use the terminal that in the south side of Juanda airport. The results showed that the existing taxiway pavement structure was able to hold the load of aircraft movements over 20 years. So that, to prepare a taxiway pavement in the south side of Juanda airport, PT. Angkasa Pura I need only overlay the existing taxiway pavement.

Keywords: pavement; taxiway

\section{Latar Belakang}

Bandar udara Juanda merupakan salah satu bandara internasional di Indonesia. Pergerakan penumpang dan pesawat terbang terus meningkat tiap tahunnya. Peningkatan pergerakan penumpang dan pesawat terbang berdampak pada kebutuhan penambahan infrastruktur di bandar udara Juanda. Sehingga PT. Angkasa Pura I selaku operator bandara Juanda merevitalisasi terminal lama yang berada di sisi selatan landas pacu bandara Juanda..Tujuannya adalah agar kapasitas infrastruktur bandar udara Juanda bertambah.

Fasilitas bandar udara yang ada di sisi selatan landas pacu bandara Juanda meliputi gedung terminal, apron dan landas ancang. Dalam usaha revitalisasi terminal sisi selatan, gedung terminal yang ada sekarang akan dirobohkan dan dibangun gedung terminal yang baru. Sedangkan apron dan landas ancang akan dievaluasi terlebih dahulu kondisinya mengingat terminal tersebut sudah tidak beroperasi selama kurang lebih 8 tahun. Makalah ini akan membahas evaluasi perkerasan landas ancang dari terminal yang beraada di sisi selatan landas pacu bandara Juanda.

\section{Permasalahan}

Sesuai dengan uraian latar belakang di atas, permasalahan yang dihadapai dalam penulisan makalah ini adalah:

1. Bagaimana struktur perkerasan landas ancang sisi selatan landas pacu bandara Juanda?

2. Berapakah frekuensi pergerakan pesawat yang diprediksi akan menggunakan landas ancang sisi selatan landas pacu bandara Juanda?

3. Apakah konstruksi perkerasan landas ancang sisi selatan landas pacu bandara Juanda yang ada sekarang masih mampu menahan beban pergerakan pesawat masa mendatang?

\section{Tujuan}

Dari permasalahan yang telah disampaikan di atas, maka tujuan penulisan makalah ini adalah:

1. Mengetahui struktur perkerasan landas ancang sisi selatan landas pacu bandara Juanda?

2. Mengetahui frekuensi pergerakan pesawat yang diprediksi akan menggunakan landas ancang sisi selatan landas pacu bandara Juanda?

3. Mengetahui kemampuan konstruksi perkerasan landas ancang sisi selatan landas pacu bandara Juanda yang ada sekarang masih dalam menahan beban pergerakan pesawat masa mendatang 


\section{Metodologi}

Agar tujuan penulisan makalah ini tercapai, maka diperlukan bagan alir sebagai berikut:

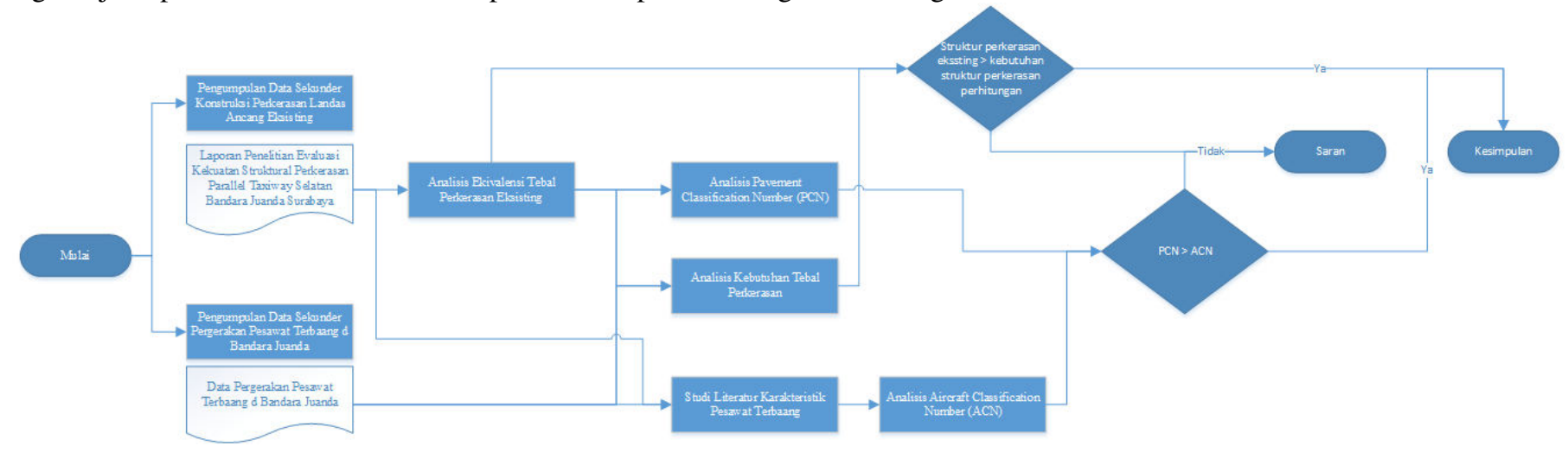

Gambar 1. Bagan Alir Penelitian

\section{Analisis dan Pembahasan}

\subsection{Analisis Pavement Classification Number (PCN)}

\subsubsection{Ekivalensi Tebal Perkerasan Eksisting}

Dalam analisis ekivalensi tebal perkerasan eksisting ke tebal perkerasan bandara standard FAA, akan menggunakan 2 (dua) metode, yakni Metode FAA dan Metode FAA modifikasi. Sesuai dengan as built drawing perkerasan runway dan taxiway pada Laporan Penelitian Evaluasi Kekuatan Struktural Perkerasan Parallel Taxiway Selatan Bandara Juanda Surabaya, tipikal perkerasan taxiway sisi selatan Bandara Juanda adalah sebagai berikut:

a. Lapisan overlay, yang berupa, meterial beraspal dengan tebal $60 \mathrm{~mm}(=2,36$ inch $)$

b. Surface course lama, terdiri dari lapisan asphaltic concrete wearing course (AC-WC), yaitu lapisan pertama setebal 540mm (=21,26 inch).

c. Base course, terdiri dari agregat base dengan tebal $500 \mathrm{~mm}(19,69$ inch).

d. Subgrade, yang terdiri dari material batu karang.

Sebelum dianalisis kekuatannya, tebal perkerasan taxiway bandara Juanda harus diekivalensi terlebih dahulu ke standar tebal perkerasan bandara FAA. Untuk ekivalensi perkerasan eksisting menggunakan software MS Excel yang merupakan pendukung software COMFAA 3.0. Hasil analisis ekivalensi tebal perkerasan eksisting dengan software MS Excel pendukung software COMFAA 3.0 dapat dilihat pada Gambar 2. 


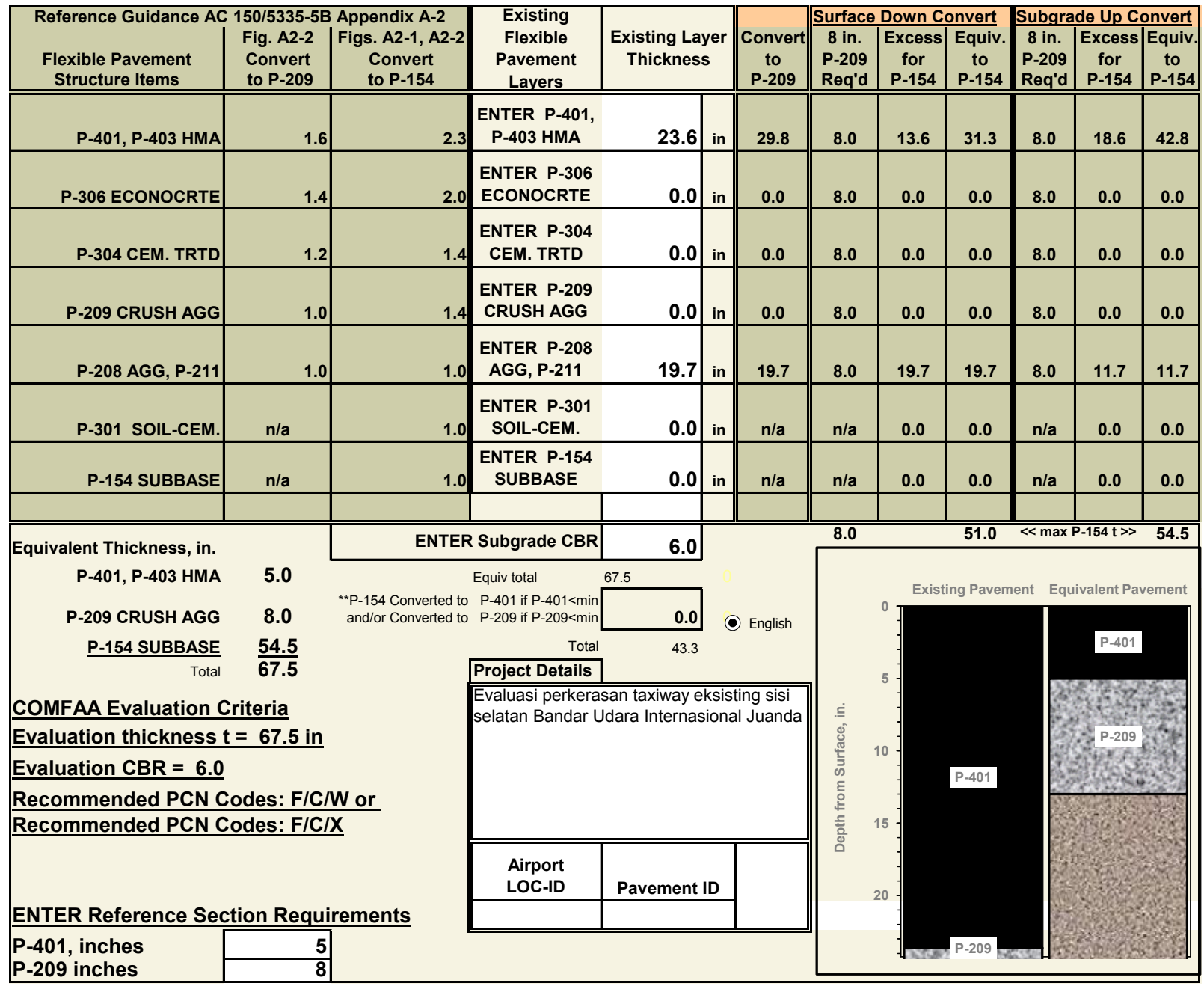

Gambar 2. Perhitungan Ekivalensi Tebal Eksisitng Perkerasan Taxiway Sisi Selatan Bandara Juanda

Hasil analisis ekivalensi tebal perkerasan eksisting, diperoleh tebal perkerasan eksisting perkerasan taxiway bandara menurut standar FAA adalah sebagai berikut:

a. Asphalt Concrete (P-401)

b. Crushed Agregate Base Course (P-209)

c. Subbase Course (P-154)

d. Tebal total perkerasan hasil ekivalensi tebal eksisitng ke tebal standard FAA

$$
\begin{aligned}
& =5 \mathrm{inch} \\
& =8 \mathrm{inch} \\
& =54,5 \mathrm{inch} \\
& =67,5 \mathrm{inch}
\end{aligned}
$$

Perhitungan ekivalensi tebal perkerasan eksisting Metode FAA modifikasi dilakukan karena pada program bantu (software) MS Excel yang merupakan pendukung software COMFAA 3.0 tersebut tidak memperhitungkan umur perkerasan. Padahal umur perkerasan akan mempengaruhi indek/tingkat pelayanan dari perkerasan tersebut terhadap lalu lintas pesawat yang akan melewati perkerasan tersebut. Sehingga untuk menghitung tebal ekivalen digunakan Metode ITP (Indeks Tebal Perkerasan). Berdasarkan pengalaman penulis, indeks permukaan perkerasan taxiway sisi selatan Bandar Udara Unternasional Juanda saat akan dievaluasi (IPt) diasumsikan sebesar 2,5 (artinya jalan dengan kondisi permukaan masih cukup baik). Sedangkan untuk sebuah perkerasan Laston (AC) pada saat pertama dibuka untuk lalu lintas mempunyai nilai indeks permukaan (IPo) sebesar 4. Sehingga diprakirakan umur perkerasan taxiway sisi selatan Bandar Udara Unternasional Juanda saat ini adalah (IPt/IPo)* $100 \%$ $=(2,5 / 4) * 100 \%=62,5 \%$ dari setelah dilapis ulang.

Indeks Tebal Perkerasan (ITP) dipengaruhi oleh kekuatan material tiap lapis perkerasan dan tebal tiap lapis perkerasan. Berdasarkan data as built drawing perkerasan taxiway sisi selatan Bandara Juanda, diketahui tebal perkerasan dan prakiraan kekuatan relatif materialnya dapat dilihat pada Gambar 3. 


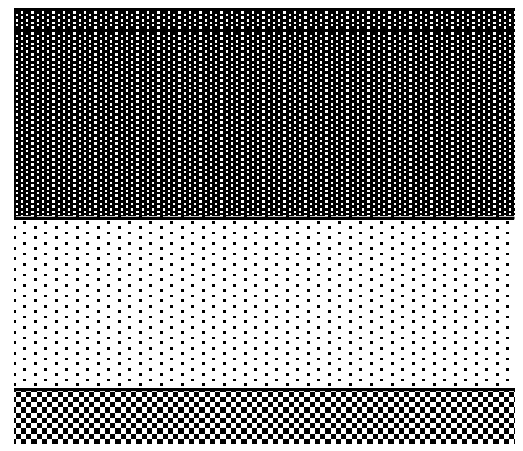

$6 \mathrm{~cm}(=2,36 \mathrm{in})$ Overlay; $a=0,44$

$54 \mathrm{~cm}(=21,26 \mathrm{in})$ Surface lama AC; $a=0,28$

50cm (= 19,69in) Base Course; $a=0,14$

\section{Subgrade}

Gambar 3. Tebal dan Prakiraan Kekuatan Relatif Material Perkerasan Eksisting

Berdasarkan data tebal perkerasan dan prakiraan koefisen kekuatan material (a). maka prakiraan indeks tebal perkerasan (ITP) Bandara Juanda saat ini adalah:

$$
62,5 \% *(0,44 * 6+0,28 * 54+0,14 * 50)=15,475 \mathrm{~cm}
$$

Setelah diketahui ITP perkerasan saat ini selanjutnya adalah mencari tebal perkerasan yang ekivalen dengan tebal perkerasan bandara standard FAA dimana ada beberapa asumsi yang harus diambil, yakni:

a. Tebal surface course adalah 5 inch $(=12,7 \mathrm{~cm}) ; \mathrm{a}=0,44$

b. Tebal base course adalah 8 inch $(=20,32 \mathrm{~cm}) ; \mathrm{a}=0,14$

c. Tebal subbase course akan menyesuaikan dengan koefisien kekuatan material (a) = 0,10 dan ITP ekivalen adalah $15,475 \mathrm{~cm}$. Dengan asumsi-asumsi di atas, diperoleh tebal perkerasan ekivalen standard FAA yang dapat dilihat pada Gambar 4.

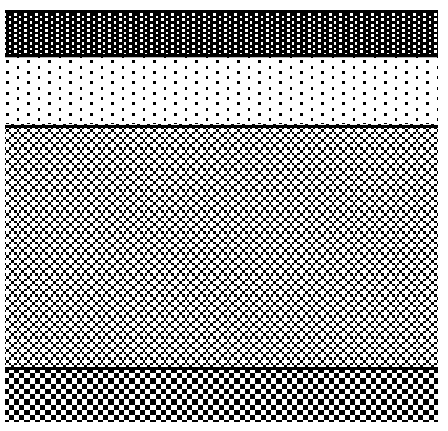

$$
\begin{aligned}
& 12.7 \mathrm{~cm} \text { (= 5in) Surface Course; } a=0,44 \\
& 20.32 \mathrm{~cm} \text { (= 8in) Base Course; } a=0,14
\end{aligned}
$$

70.42 (= 27,72in) Subbase Course; $a=0.1$

\section{Subgrade}

Gambar 4. Tebal Perkerasan Ekivalen Standard FAA

Dari gambar tebal perkerasan ekivalen tebal perkerasan bandara standard FAA, diperoleh tebal total perkerasan adalah $103,44 \mathrm{~cm}(=40,72$ inch $)$

\subsubsection{Prediksi Keberangkatan Pesawat Internasional Tahunan}

Terminal 2 (sisi selatan) Bandara Juanda diperuntukkan bagi penerbangan internasional dan Garuda Indonesia Airways (GIA). Sehingga untuk prediksi lalu lintas keberangkatan di Terminal 2 (sisi selatan) Bandara Udara Internasioanl Juanda berasal dari keberangkatan pesawat internasional, seluruh keberangkatan pesawat Garuda Indonesia Airways (GIA), Mandala dan Air Asia serta adanya kemungkinan Bandara Juanda didarati oleh pesawat B-744 dan B-773ER. Rekapitulasi keberangkatan pesawat terbang tahunan yang diprakirakan akan menggunakan Terminal 2 (sisi selatan) Bandara Juanda dapat dilihat pada Tabel 2.

Tabel 1. Prediksi Keberangkatan Pesawat Terbang dari Terminal 2 (Sisi Selatan) Bandara Juanda

\begin{tabular}{lccccccccc}
\hline \multicolumn{1}{c}{ Jenis Pesawat } & A-320 & A-330 & A-332 & A-333 & B-738 & B-747 & B-772 & B-773 & CRJ \\
\hline Mingguan & 191 & 8 & 1 & 1 & 194 & 7 & 4 & 10 \\
\hline Tahunan & 9932 & 416 & 52 & 52 & 10088 & 364 & 208 & 520 & 468 \\
\hline Keterangan $: B-772$ & $=B 777-200$ & & & & & &
\end{tabular}




\subsubsection{Kekuatan Tanah Dasar}

Berdasarkan informasi PCN yang dipublikasikan oleh Bandara Juanda dalam Aeronautical Information Publication (AIP) yakni 73 FCXU, maka untuk daya dukung tanah dasar (CBR) perkerasan taxiway sisi selatan adalah sebesar 6\% (kode C)

Namun demikian berdasarkan pengamatan penulis, karena tanah subgrade berupa tanah urugan sirtu (dominan pasir sungai, dari Kali Porong - Jatim) yang dipadatkan dengan baik dengan ketebalan minimal sekitar 3 meter di atas lapisan tanah aslinya (tanah dominan lempung), maka California Bearing Ratio (CBR) tanah subgrade supaya dianggap dari mutu yang paling tinggi $($ CBR $\min =15 \%)$. Jadi bila diperkirakan perhitungan ketebalan lapisan perkerasan s/d lapisan pondasi atas dan pondasi bawah di atas tanah subgrade adalah total $120 \mathrm{~cm}$, masih terdapat lapisan tanah urugan sedikitnya $180 \mathrm{~cm}$ di bawahnya yang berupa tanah pasir padat.

\subsubsection{Analisis Kekuatan Perkerasan Taxiway Sisi Selatan Bandara Juanda}

\subsubsection{Metode FAA}

Kekuatan perkerasan taxiway sisi selatan bandara Juanda ditentukan berdasarkan Metode PCN dan dibantu oleh software COMFAA 3.0. Dalam Metode PCN, data-data yang harus disiapkan untuk dimasukkan dalam software COMFAA 3.0 adalah data daya dukung tanah dasar, tebal ekivalen dan annual departures rencana yang akan melewati sisi selatan taxiway bandara Juanda. Masing-masing data yang akan dimasukkan dalam software COMFAA 3.0 sudah dianalasis pada subbab sebelumnya. Daya dukung tanah dasar (CBR) menggunakan 3 skenario yakni 6\%,10\% dan 15\%. Untuk tebal ekivalen perkerasan eksisting berdasarkan Metode FAA adalah 67,5 inches. Hasil analisis kekuatan perkerasan dengan tebal ekivalen perkerasan eksisting berdasarkan Metode FAA dapat dilihat pada Tabel 2 dan Gambar 5 sampai dengan Gambar 7.

Tabel 2. Output Perhitungan Kekuatan Perkeraan Metode PCN FAA Dengan Software COMFAA

\begin{tabular}{|c|c|c|c|c|c|c|c|c|c|c|c|c|c|}
\hline \multirow{2}{*}{ No } & \multirow{2}{*}{ Plane } & \multirow{2}{*}{ GWin } & \multirow{2}{*}{ AD out } & \multirow{2}{*}{$\operatorname{COV} 20 \mathrm{yr}$} & \multicolumn{3}{|c|}{ CBR 6\% } & \multicolumn{3}{|c|}{ CBR 10\% } & \multicolumn{3}{|c|}{ CBR 15\% } \\
\hline & & & & & $\mathrm{ACN}$ in & 6Dt & COV to $F$ & $\mathrm{ACN}$ in & 6Dt & COV to $\mathrm{F}$ & $\mathrm{ACN}$ in & $6 \mathrm{Dt}$ & COV to F \\
\hline 1 & CRJ 1000 & 92300 & 468 & $2.54 \mathrm{E}+03$ & 27.5 & 21.51 & $2.52 \mathrm{E}+149$ & 24.2 & 15.11 & $1.01 \mathrm{E}+304$ & 22.6 & 11.49 & $1.01 \mathrm{E}+304$ \\
\hline 2 & A320 Twin opt & 172842 & 9932 & $5.35 \mathrm{E}+04$ & 47.3 & 34.71 & $1.01 \mathrm{E}+304$ & 42.9 & 24.72 & $1.01 \mathrm{E}+304$ & 41 & 18.78 & $1.01 \mathrm{E}+304$ \\
\hline 3 & B777-300 ER & 777000 & 520 & $7.97 \mathrm{E}+03$ & 89.3 & 42.56 & $1.01 \mathrm{E}+304$ & 71.3 & 28.54 & $1.01 \mathrm{E}+304$ & 63.8 & 21.12 & $1.01 \mathrm{E}+304$ \\
\hline 4 & B777-200 ER & 657000 & 208 & $3.03 \mathrm{E}+03$ & 68 & 35.26 & $1.71 \mathrm{E}+106$ & 55.4 & 24.03 & $1.01 \mathrm{E}+304$ & 49.1 & 17.77 & $1.01 \mathrm{E}+304$ \\
\hline 5 & B747-400 & 877000 & 364 & $4.18 \mathrm{E}+03$ & 72.6 & 36.57 & $1.01 \mathrm{E}+304$ & 59.3 & 24.92 & $1.01 \mathrm{E}+304$ & 53.2 & 18.56 & $1.01 \mathrm{E}+304$ \\
\hline 6 & B737-800 & 174700 & 10088 & $5.67 \mathrm{E}+04$ & 50.3 & 35.79 & $1.01 \mathrm{E}+304$ & 45.3 & 25.53 & $1.28 \mathrm{E}+285$ & 42.8 & 19.31 & $1.01 \mathrm{E}+304$ \\
\hline 7 & B737-900 ER & 188200 & 364 & $2.06 \mathrm{E}+03$ & 56 & 30.09 & $1.07 \mathrm{E}+257$ & 50.8 & 21.53 & $1.01 \mathrm{E}+304$ & 47.9 & 16.46 & $1.01 \mathrm{E}+304$ \\
\hline 8 & A330-300 std & 509047 & 468 & $5.00 \mathrm{E}+03$ & 72.6 & 37.13 & $1.01 \mathrm{E}+304$ & 62.7 & 26 & $1.01 \mathrm{E}+304$ & 57.7 & 19.58 & $1.01 \mathrm{E}+304$ \\
\hline 9 & A330-200 std & 509047 & 52 & $5.52 \mathrm{E}+02$ & 71.6 & 30.77 & $1.01 \mathrm{E}+304$ & 61.9 & 21.84 & $3.45 \mathrm{E}+186$ & 57 & 16.66 & $1.01 \mathrm{E}+304$ \\
\hline
\end{tabular}

Tabel 2. Output Perhitungan Kekuatan Perkeraan Metode PCN FAA Dengan Software COMFAA (lanjutan)

\begin{tabular}{|c|c|c|c|c|c|c|c|c|c|c|c|}
\hline \multirow{2}{*}{ No. } & \multirow{2}{*}{ Plane } & \multirow{2}{*}{ Pto TC } & \multicolumn{3}{|c|}{ CBR 6\% } & \multicolumn{3}{|c|}{ CBR 10\% } & \multicolumn{3}{|c|}{ CBR 15\% } \\
\hline & & & CDF t & GW cdf & PCN cdf & CDF t & GW cdf & PCN cdf & CDF t & GW cdf & PCN cdf \\
\hline 1 & CRJ 1000 & 1 & 38.17 & 272935.3 & 92.5 & 27.85 & 475891.9 & 165.1 & 14.7 & 1357667 & 499.6 \\
\hline 2 & A320 Twin opt & 1 & 51.31 & 285179.5 & 87.4 & 37.48 & 487921.1 & 156.1 & 19.65 & 1367872 & 492.7 \\
\hline 3 & B777-300 ER & 1 & 52.72 & 1090329 & 151.5 & 35 & 1827168 & 269.8 & 23.09 & 3183367 & 545.2 \\
\hline 4 & B777-200 ER & 1 & 35.26 & 1538126 & 245.8 & 30.67 & 1835205 & 270.2 & 20.34 & 3198106 & 545.8 \\
\hline 5 & B747-400 & 1 & 54.32 & 1217098 & 118.9 & 36.68 & 2052504 & 212.7 & 21.74 & 4157682 & 517.5 \\
\hline 6 & B737-800 & 1 & 52.25 & 280582.5 & 88.5 & 38.44 & 480198.3 & 157.9 & 20.14 & 1352625 & 493.9 \\
\hline 7 & B737-900 ER & 1 & 54.84 & 276861.5 & 88.5 & 40.54 & 472941.8 & 157.8 & 21.26 & 1325040 & 495 \\
\hline 8 & A330-300 std & 1 & 54.53 & 680201.1 & 112.1 & 36.74 & 1147063 & 200.4 & 22.55 & 2313998 & 504.8 \\
\hline 9 & A330-200 std & 1 & 54.13 & 686945.6 & 112.1 & 21.84 & 2508307 & 602.3 & 22.4 & 2336942 & 504.8 \\
\hline
\end{tabular}




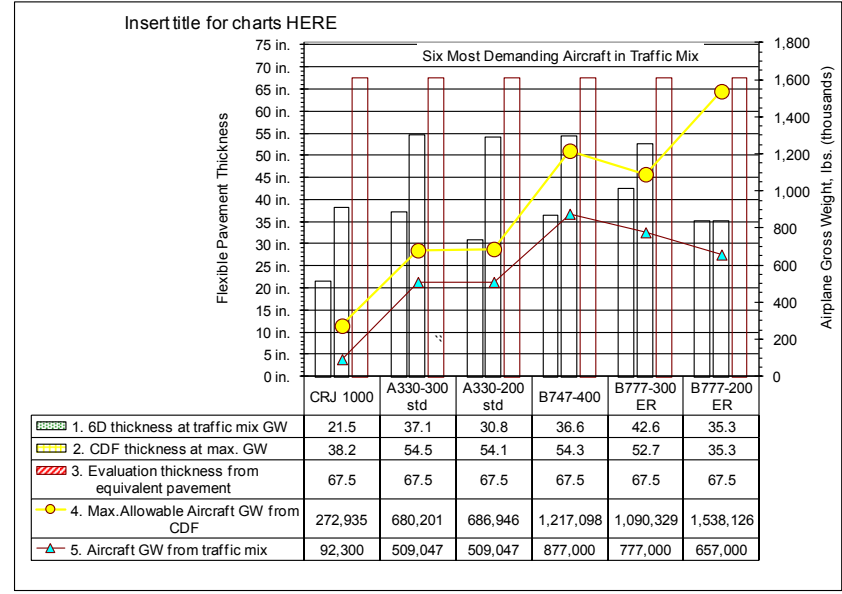

(a) Perbandingan Tebal Perkerasan Ekivalen Dengan Kebutuhan Tebal Perkerasan

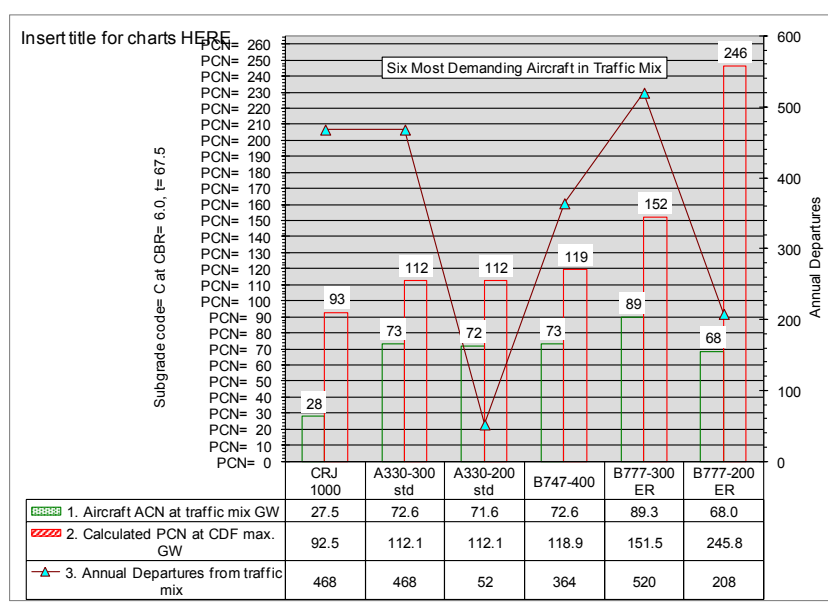

(b). Perbandingan ACN dan PCN Bandar Udara Internasional Juanda (Tebal Ekivalen Berdasar Metode FAA

Gambar 5. Hasil Analisis Kekuatan Perkerasan Taxiway Sisi Selatan Bandara Juanda, Metode FAA, CBR 6\%

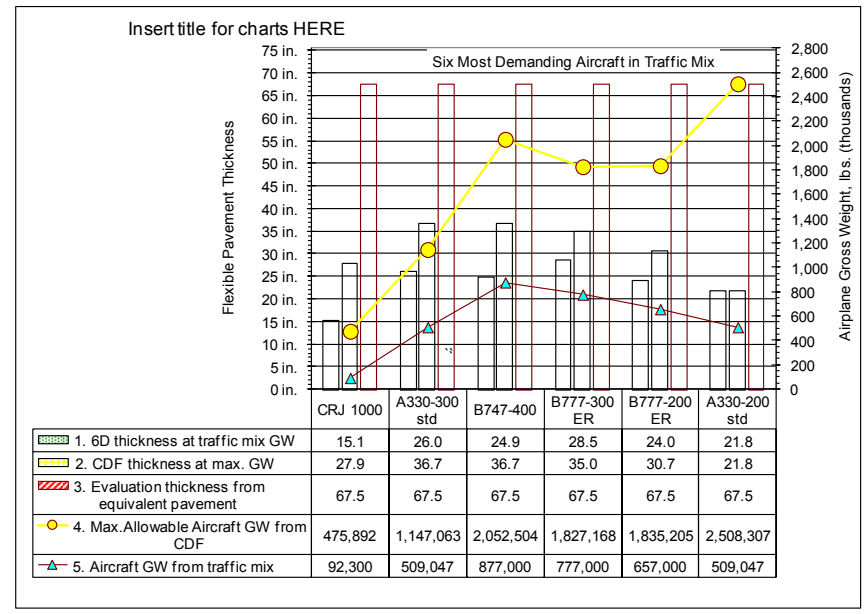

(a) Perbandingan Tebal Perkerasan Ekivalen Dengan Kebutuhan Tebal Perkerasan

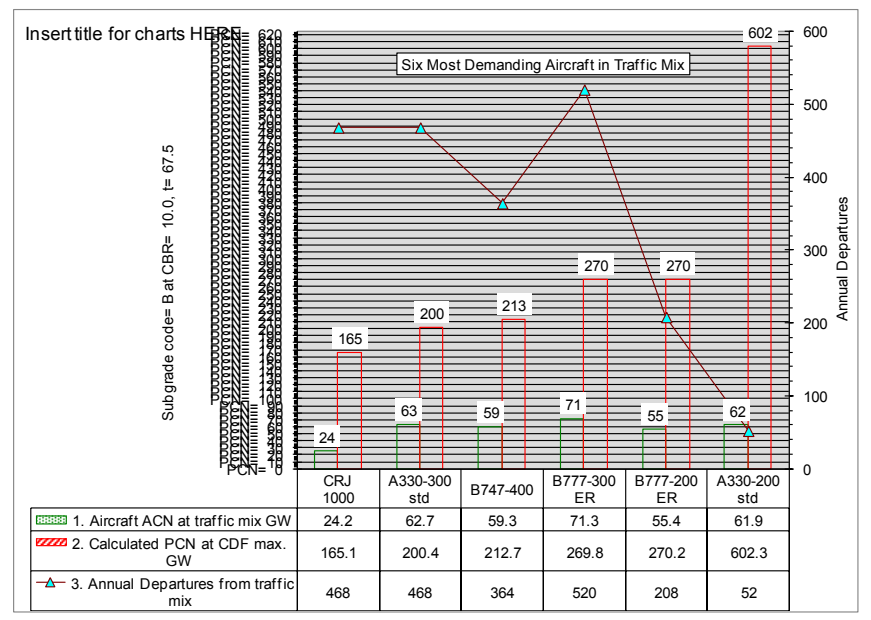

(b). Perbandingan ACN dan PCN Bandar Udara Internasional Juanda (Tebal Ekivalen Berdasar Metode FAA

Gambar 6. Hasil Analisis Kekuatan Perkerasan Taxiway Sisi Selatan Bandara Juanda, Metode FAA, CBR 10\%

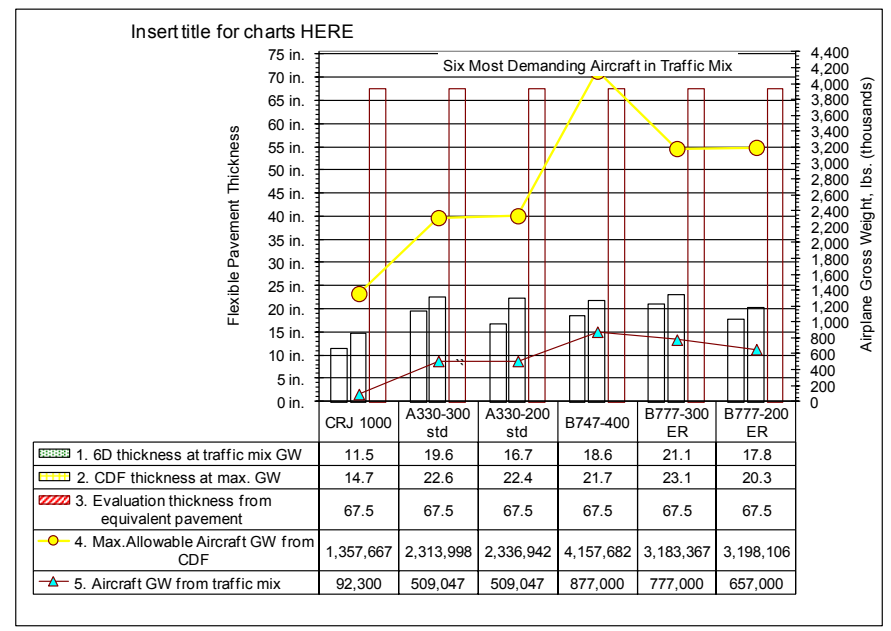

(a) Perbandingan Tebal Perkerasan Ekivalen Dengan Kebutuhan Tebal Perkerasan

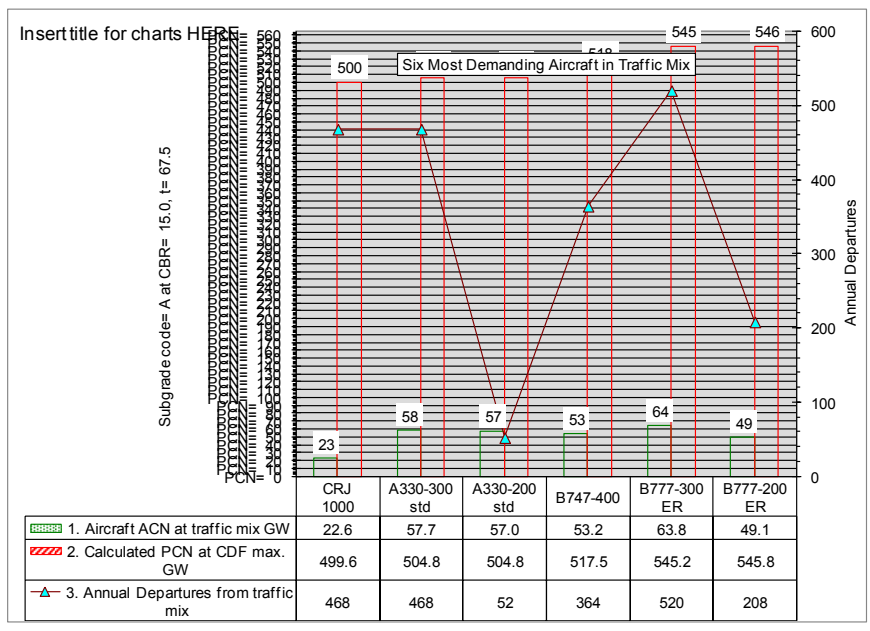

(b). Perbandingan ACN dan PCN Bandar Udara Internasional Juanda (Tebal Ekivalen Berdasar Metode FAA 


\subsubsection{Metode FAA Modifikasi}

Hasil analisis kekuatan perkerasan dengan tebal ekivalen perkerasan eksisting berdasarkan Metode FAA dapat dilihat pada Tabel 3 dan Gambar 8 sampai dengan Gambar 10.

Tabel 3. Output Perhitungan Kekuatan Perkeraan Metode PCN FAA Modifikasi Dengan Software COMFAA

\begin{tabular}{|c|c|c|c|c|c|c|c|c|c|c|c|c|c|}
\hline \multirow{2}{*}{ No } & \multirow{2}{*}{ Plane } & \multirow{2}{*}{ GWin } & \multirow{2}{*}{ AD out } & \multirow{2}{*}{ COV 20yr } & \multicolumn{3}{|c|}{ CBR 6\% } & \multicolumn{3}{|c|}{ CBR 10\% } & \multicolumn{3}{|c|}{ CBR 15\% } \\
\hline & & & & & $\mathrm{ACN}$ in & 6Dt & COV to F & $\mathrm{ACN}$ in & $6 \mathrm{Dt}$ & COV to F & $\mathrm{ACN}$ in & 6Dt & COV to F \\
\hline 1 & CRJ 1000 & 92300 & 468 & $2.54 \mathrm{E}+03$ & 27.5 & 21.51 & $1.01 \mathrm{E}+304$ & 24.2 & 15.11 & $1.01 \mathrm{E}+304$ & 22.6 & 11.49 & $1.12 \mathrm{E}+248$ \\
\hline 2 & A320 Twin opt & 172842 & 9932 & $5.35 \mathrm{E}+04$ & 47.3 & 34.71 & $3.15 \mathrm{E}+06$ & 42.9 & 24.72 & $1.01 \mathrm{E}+304$ & 41 & 18.78 & $1.01 \mathrm{E}+304$ \\
\hline 3 & B777-300 ER & 777000 & 520 & $7.97 \mathrm{E}+03$ & 89.3 & 42.56 & $3.56 \mathrm{E}+03$ & 71.3 & 28.54 & $1.01 \mathrm{E}+304$ & 63.8 & 21.12 & $1.01 \mathrm{E}+304$ \\
\hline 4 & B777-200 ER & 657000 & 208 & $3.03 \mathrm{E}+03$ & 68 & 35.26 & $9.38 \mathrm{E}+04$ & 55.4 & 24.03 & $1.01 \mathrm{E}+304$ & 49.1 & 17.77 & $1.01 \mathrm{E}+304$ \\
\hline 5 & B747-400 & 877000 & 364 & $4.18 \mathrm{E}+03$ & 72.6 & 36.57 & $2.33 \mathrm{E}+04$ & 59.3 & 24.92 & $1.01 \mathrm{E}+304$ & 53.2 & 18.56 & $5.96 \mathrm{E}+117$ \\
\hline 6 & B737-800 & 174700 & 10088 & $5.67 \mathrm{E}+04$ & 50.3 & 35.79 & $1.44 \mathrm{E}+06$ & 45.3 & 25.53 & $1.01 \mathrm{E}+304$ & 42.8 & 19.31 & $1.01 \mathrm{E}+304$ \\
\hline 7 & B737-900 ER & 188200 & 364 & $2.06 \mathrm{E}+03$ & 56 & 30.09 & $3.26 \mathrm{E}+05$ & 50.8 & 21.53 & $1.01 \mathrm{E}+304$ & 47.9 & 16.46 & $1.01 \mathrm{E}+304$ \\
\hline 8 & A330-300 std & 509047 & 468 & $5.00 \mathrm{E}+03$ & 72.6 & 37.13 & $2.43 \mathrm{E}+04$ & 62.7 & 26 & $2.75 \mathrm{E}+75$ & 57.7 & 19.58 & $1.07 \mathrm{E}+121$ \\
\hline 9 & A330-200 std & 509047 & 52 & $5.52 \mathrm{E}+02$ & 71.6 & 30.77 & $2.81 \mathrm{E}+04$ & 61.9 & 21.84 & $1.01 \mathrm{E}+304$ & 57 & 16.66 & $1.01 \mathrm{E}+304$ \\
\hline
\end{tabular}

Tabel 3. Output Perhitungan Kekuatan Perkeraan Metode PCN FAA Modifikasi Dengan Software COMFAA (lanjutan)

\begin{tabular}{|c|c|c|c|c|c|c|c|c|c|c|c|}
\hline \multirow{2}{*}{ No. } & \multirow{2}{*}{ Plane } & \multirow{2}{*}{ Pto TC } & \multicolumn{3}{|c|}{ CBR 6\% } & \multicolumn{3}{|c|}{ CBR 10\% } & \multicolumn{3}{|c|}{ CBR 15\% } \\
\hline & & & CDF t & GW cdf & PCN cdf & CDF t & GW cdf & PCN cdf & CDF t & GW cdf & PCN cdf \\
\hline 1 & CRJ 1000 & 1 & 38.17 & 104036.1 & 31.7 & 27.85 & 181325.4 & 56.4 & 21.27 & 286765.7 & 93.9 \\
\hline 2 & A320 Twin opt & 1 & 41.83 & 165221.2 & 44.6 & 37.48 & 198295.2 & 50.8 & 28.05 & 310672.7 & 83.3 \\
\hline 3 & B777-300 ER & 1 & 42.98 & 726571.2 & 80.2 & 35 & 940264.9 & 95 & 25.54 & 1420599 & 155.6 \\
\hline 4 & B777-200 ER & 1 & 41.74 & 636943.2 & 64.8 & 30.67 & 943860.1 & 95.1 & 22.42 & 1427154 & 155.7 \\
\hline 5 & B747-400 & 1 & 42.74 & 822846.4 & 65.9 & 36.68 & 1002195 & 71.6 & 18.57 & 2554833 & 260.7 \\
\hline 6 & B737-800 & 1 & 41.93 & 166121.2 & 47.2 & 38.44 & 192642.5 & 51.3 & 29.02 & 302013.5 & 84.2 \\
\hline 7 & B737-900 ER & 1 & 42.21 & 176973.4 & 51.9 & 40.54 & 189704.8 & 51.3 & 30.81 & 297979.7 & 84.6 \\
\hline 8 & A330-300 std & 1 & 42.64 & 478310 & 66.4 & 26 & 971951.5 & 155.5 & 24.62 & 1037279 & 147.4 \\
\hline 9 & A330-200 std & 1 & 42.58 & 479139.9 & 65.6 & 36.48 & 591621.1 & 75.5 & 26.92 & 909249.1 & 122.1 \\
\hline
\end{tabular}

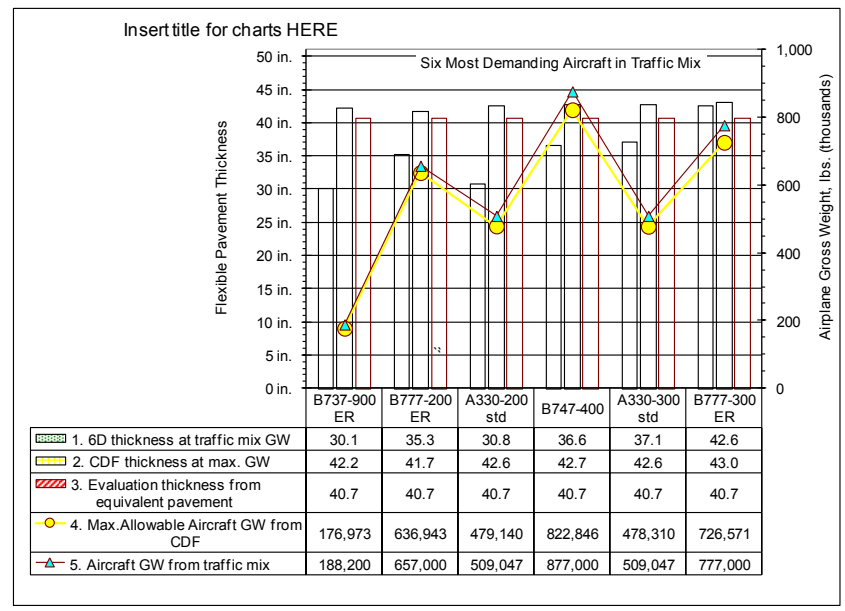

(a) Perbandingan Tebal Perkerasan Ekivalen Dengan Kebutuhan Tebal Perkerasan

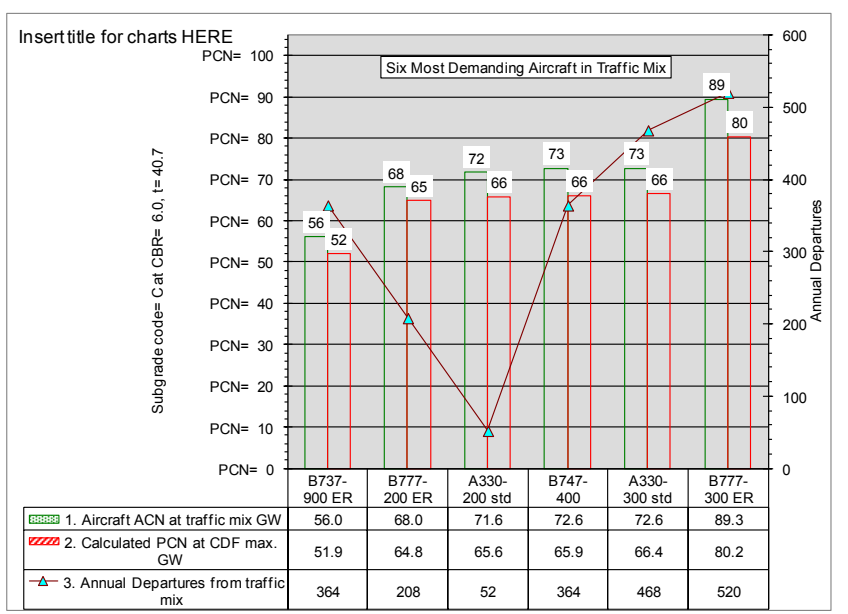

(b). Perbandingan ACN dan PCN Bandar Udara Internasional Juanda (Tebal Ekivalen Berdasar Metode FAA 


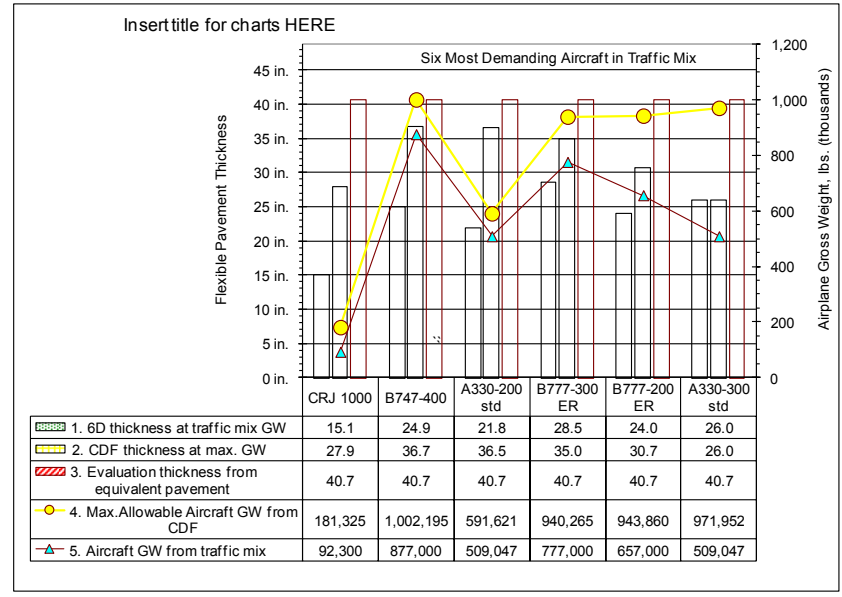

(a) Perbandingan Tebal Perkerasan Ekivalen Dengan Kebutuhan Tebal Perkerasan

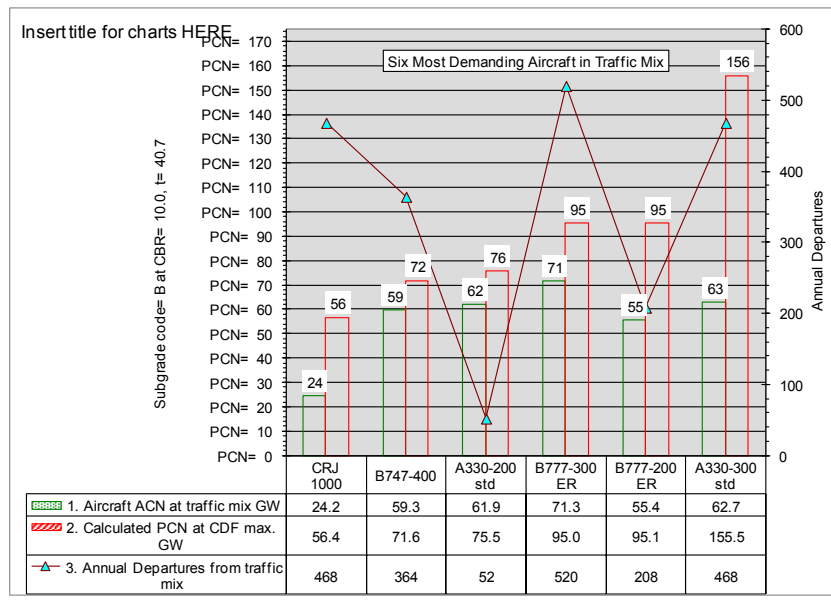

(b). Perbandingan ACN dan PCN Bandar Udara Internasional Juanda (Tebal Ekivalen Berdasar Metode FAA

Gambar 9. Hasil Analisis Kekuatan Perkerasan Taxiway Sisi Selatan Bandara Juanda, Metode FAA Modfikikasi, CBR 10\%

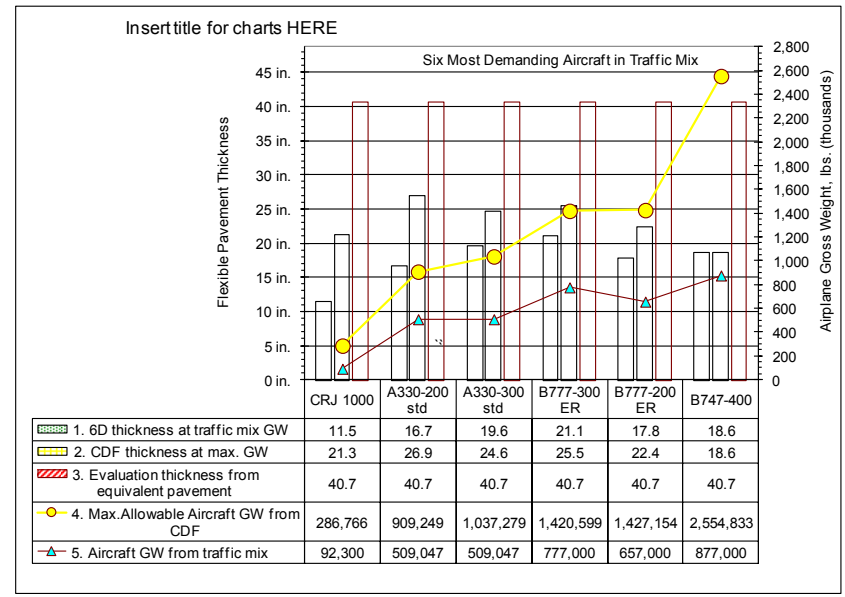

(a) Perbandingan Tebal Perkerasan Ekivalen Dengan Kebutuhan Tebal Perkerasan

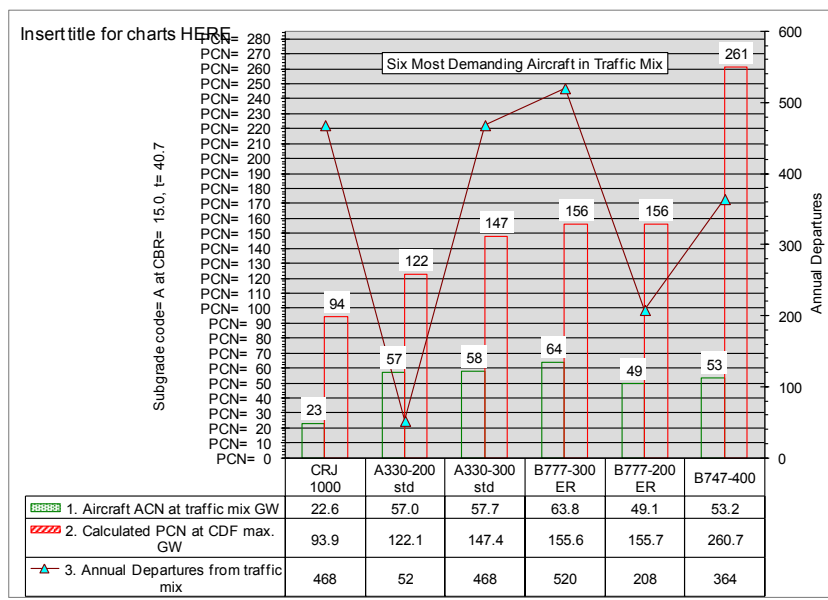

(b). Perbandingan ACN dan PCN Bandar Udara Internasional Juanda (Tebal Ekivalen Berdasar Metode FAA

Gambar 10. Hasil Analisis Kekuatan Perkerasan Taxiway Sisi Selatan Bandara Juanda, Metode FAA Modfikikasi, CBR 15\%

\subsection{Analisis Aircraft Classification Number (ACN)}

\subsubsection{Analisis Aircraft Classification Number (ACN) Eksistng}

Untuk penentuan nilai Aircraft Classification Number (ACN) bandara Juanda dipengaruhi berat pesawat terbang denngan rute tujuan penerbangan internasional. Variabel dari bobot pesawat terbang yang bisa berubah-ubah terkait dengan rute penerbangan adalah penumpang dan bahan bakar. Namun untuk analisi penentuan ACN pada bandara Juanda ini diasumsikan bahwa penumpang terisi penuh. Sedangkan untuk bahan bakar yang diperlukan akan mengikuti aturan penerbangan internasional yakni bahan bakar yang dibutuhkan dari bandara asal ke bandara tujuan ditambah dengan bahan bakar ekstra untuk kondisi darurat \pm 2 (dua) jam perjalanan di udara. untuk estimasi jarak tempuh dan waktu tempuh penerbangan internasional dari bandara Juanda dapat dilihat pada Tabel 4.

Tabel 4. Estimasi Jarak Tempuh dan Waktu Tempuh Penerbangan Internasional Dari Bandara Juanda

\begin{tabular}{|c|c|c|c|c|}
\hline \multirow{2}{*}{ Tujuan } & \multicolumn{2}{|c|}{ Jarak } & \multirow{2}{*}{ Jenis Pesawat } & \multirow{2}{*}{ Prediksi Waktu Tempuh Normal } \\
\hline & Kilometer & Mil & & \\
\hline Penang (PEN) & 1959 & 1217 & A320 & 3 jam 55 menit \\
\hline Johor Bahru (JHB) & 1406 & 873 & A320 & 3 jam 20 menit \\
\hline Kuala Lumpur (KUL) & 1649 & 1025 & A320 & 3 jam 30 menit \\
\hline
\end{tabular}




\begin{tabular}{|c|c|c|c|c|}
\hline \multirow{2}{*}{ Tujuan } & \multicolumn{2}{|c|}{ Jarak } & \multirow{2}{*}{ Jenis Pesawat } & \multirow{2}{*}{ Prediksi Waktu Tempuh Normal } \\
\hline & Kilometer & Mil & & \\
\hline Singapura (SIN) & 1359 & 844 & $\mathrm{~A} 320$ & 3 jam 15 menit \\
\hline Bangkok (DMK) & 2701 & 1679 & A320 & 3 jam 50 menit \\
\hline \multirow[t]{2}{*}{ Taipei (TPE) } & 3705 & 2302 & A333 (non direct) & - \\
\hline & 3705 & 2302 & A332 (direct) & $6 \mathrm{jam}$ \\
\hline \multirow[t]{2}{*}{ Hong Kong (HKG) } & 3284 & 2041 & B772 & 5 jam 45 menit \\
\hline & 3284 & 2041 & A333 & 5 jam 35 menit \\
\hline Jeddah (JED) & 8626 & 5360 & B747 & 8 jam 15 menit \\
\hline Bandar Seri Begawan (BWN) & 1371 & 852 & A320 & 3 jam 10 menit \\
\hline
\end{tabular}

Untuk standard hubungan bobot maksimum pesawat terbang dengan jarak tempuh maksimum masing-masing jenis pesawat dapat dilihat pada Tabel 5 .

Tabel 5. Perbandingan Bobot Maksimum dan Jarak Tempuh Maksimum Masing-masing Jenis Pesawat Keberangkatan Internasional di Bandara Juanda

\begin{tabular}{|c|c|c|c|c|}
\hline No. & Jenis Pesawat & $\begin{array}{c}\text { Bahan Bakar Maksimum } \\
(\mathbf{k g})\end{array}$ & $\begin{array}{c}\text { Jarak Tempuh Maksimum dengan Payload dan } \\
\text { Bahan Bakar Maksimum }(\mathbf{k m})\end{array}$ & $\begin{array}{c}\text { Bahan Bakar/ Jarak Tempuh } \\
(\mathbf{k g} / \mathbf{k m})\end{array}$ \\
\hline 1 & A-320 & 29,659 & 6,500 & 2.677 \\
\hline 2 & A-332 & 109,185 & 13,900 & 7.855 \\
\hline 3 & A-333 & 76,561 & 11,900 & 6.434 \\
\hline 4 & B-772 & 94,240 & 9,700 & 9.715 \\
\hline 5 & B-744 & 164,064 & 13,450 & 12.198 \\
\hline
\end{tabular}

Selanjutnya setelah diketahui keperluan bahan bakar/jarak tempuh perjalanan penerbangan internasioanl adalah menentukan gross weight pesawat terbang tujuan internasional. Gross weight pesawat terbang diperoleh dari penjumlahan penggunaan bahan bakar berdasarkan tujuan penerbangan berdasarkan analog penggunaan bahan bakar per kilometer jarak tempuh dengan berat kososng pesawat termasuk kru pesawat (operating empty weight, OEW) dan berat penumpang, bagasi penumpang serta kargo (payload, $P L$ ). Asumsi berat penumpang, bagasi penumpang serta kargo (payload, $P L$ ) adalah penumpang terisi penuh. Untuk gross weight dengan tujuan penerbangan internasional di Bandara Juanda dapat dilihat pada Tabel 6.

Tabel 6. Prakiraan Berat Pesawat Terbang Tujuan Internasioan di Bandara Juanda

\begin{tabular}{|c|c|c|c|c|c|c|c|c|}
\hline No. & Tujuan & Jarak (km) & $\begin{array}{c}\text { Jarak + } 2 \text { jam } \\
(\mathbf{k m})\end{array}$ & $\begin{array}{c}\text { Jenis } \\
\text { Pesawat }\end{array}$ & $\begin{array}{c}\text { Bahan Bakar/ Jarak } \\
\text { Tempuh (kg/km) }\end{array}$ & $\begin{array}{c}\text { Keperluan BBM } \\
(\mathrm{kg})\end{array}$ & $\begin{array}{c}\text { OEW + PL } \\
(\mathrm{kg})\end{array}$ & Gross Weight (kg) \\
\hline (a) & (b) & (c) & $(d)=(c)+1700$ & (e) & (f) & $(\mathrm{g})=(\mathbf{f}) *(\mathrm{~d})$ & (h) & $(\mathbf{i})=(\mathrm{g})+(\mathbf{h})$ \\
\hline 1. & PEN & 1,959 & 3,659 & A320 & 2.677 & $9,794.86$ & 61,000 & 70,795 \\
\hline 2. & JHB & 1,406 & 3,106 & A320 & 2.677 & $8,314.52$ & 61,000 & 69,315 \\
\hline 3. & KUL & 1,649 & 3,349 & A320 & 2.677 & $8,965.02$ & 61,000 & 69,965 \\
\hline 4. & SIN & 1,359 & 3,059 & A320 & 2.677 & $8,188.71$ & 61,000 & 69,189 \\
\hline 5. & DMK & 2,701 & 4,401 & A320 & 2.677 & $11,781.14$ & 61,000 & 72,781 \\
\hline \multirow[t]{2}{*}{6.} & \multirow[t]{2}{*}{ TPE } & 3,705 & 5,405 & A333 & 6.434 & $34,774.13$ & 173,000 & 207,774 \\
\hline & & 3,705 & 5,405 & A332 & 7.855 & $42,456.47$ & 168,000 & 210,45 \\
\hline \multirow[t]{2}{*}{7.} & \multirow[t]{2}{*}{$\mathrm{HKG}$} & 3,284 & 4,984 & B772 & 9.715 & $48,421.87$ & 190,470 & 238,892 \\
\hline & & 3,284 & 4,984 & A333 & 6.434 & $32,065.55$ & 173,000 & 205,066 \\
\hline 8. & JED & 8,626 & 10,326 & B744 & 12.198 & $125,957.24$ & 242,672 & 368,629 \\
\hline 9. & BWN & 1,371 & 3,071 & A320 & 2.677 & $8,220.83$ & 61,000 & 69,221 \\
\hline
\end{tabular}

Dari hasil perhitungan gross weight pesawat tujuan internasional di Bandara Juanda selanjutnya dapat diperkirakan Aircraft Classification Number (ACN) masing-masing jenis pesawat dengan menggunakan grafik yang dikeluarkan masing-masing perusahaan produsen pesawat terbang dimana selain gross weight, penentuan Aircraft Classification Number (ACN) pada grafik tersebut meninjau daya dukung tanah dasar lapisan perkerasan. Asumsi CBR tanah dasar menggunakan 3 (tiga) skenario yakni $6 \%, 10 \%$ dan $15 \%$. Untuk rute penerbangan internasional dengan jenis pesawat yang sama akan diambil pesawat dengan gross weight terbesar.

Rekapitulasii hasil analisis penentuan ACN yang dipengaruhi jenis pesawat tujuan internasional dan daya dukung tanah dasar di Bandara Juanda dapat dilihat pada Tabel 7.

Tabel 7. Rekapitulasi Analisis Penentuan ACN Pesawat Terbang Tujuan Internasional di Bandara Juanda

\begin{tabular}{|c|c|c|c|c|}
\hline \multirow{2}{*}{ No. } & \multirow{2}{*}{ Jenis Pesawat } & \multicolumn{3}{|c|}{ Aircraft Classification Number (ACN) } \\
\hline & & CBR 15\% & CBR 10\% & CBR 6\% \\
\hline 1. & A-320 & 37 & 38 & 43 \\
\hline 2. & A-332 & 50 & 53 & 60 \\
\hline 3. & A-333 & 50 & 54 & 62 \\
\hline 4. & $\mathrm{~B}-772$ & 48 & 52 & 64 \\
\hline 5. & B-744 & 37 & 40 & 48 \\
\hline
\end{tabular}




\subsubsection{Analisis Prediksi Aircraft Classification Number (ACN) Masa Mendatang}

Seiring peningkatan jumlah penumpang pada bandara Juanda, maka bandara diprediksi akan digunakan untuk kepas landas pesawat jenis baru dan kemungkinan mempunyai ukuran kebih besar dibanding jenis pesawat yang lepas landas saat ini. sehingga perlu diprediksi besarnya Aircraft Classification Number (ACN) pesawat-pesawat tersebut dengan menyesuaikan dengan panjang landas pacu Bandara Juanda saat ini. Beberapa pesawat terbang yang diprakirakan bisa mendarat di landas pacu Bandara Internasional Juanda dapat dilihat pada Tabel 8.

Tabel 8. Rekapitulasi Analisis Penentuan ACN Pesawat Terbang Tujuan Internasional di Bandara Juanda

\begin{tabular}{|c|c|c|c|c|c|}
\hline No. & Jenis Peswat & $\begin{array}{l}\text { Panjang Minimum } \\
\text { Runway (m) }\end{array}$ & $\begin{array}{c}\text { Maximum Take Off Weight, } \\
\text { MTOW }(\mathrm{Kg})\end{array}$ & $\begin{array}{c}\text { Maximum } \\
\text { Range }(\mathbf{k m})\end{array}$ & $\begin{array}{l}\text { Maximum Take Off Weight, MTOW } \\
\text { (Kg), utk Panjang Landas Pacu 3000m }\end{array}$ \\
\hline 1 & A340-200 & 2,990 & 275,000 & 15,000 & 275,000 \\
\hline 2 & A340-300 & 3,100 & 276,500 & 13,700 & 271,000 \\
\hline 3 & A340-500 & 3,050 & 372,000 & 16,060 & 360,000 \\
\hline 4 & A340-600 & 3,100 & 368,000 & 14,350 & 360,000 \\
\hline 5 & B747-8 & 3,090 & 447,696 & 15,000 & 438,000 \\
\hline 6 & B767-300ER & 2,530 & 186,880 & 11,090 & 182,000 \\
\hline 7 & B767-400ER & 3,109 & 204,120 & 10,418 & 202,000 \\
\hline 8 & B777-300ER & 3,050 & 351,500 & 14,690 & 280,000 \\
\hline
\end{tabular}

Rekapitulasi perhitungan Aircraft Classification Number (ACN) tiap jenis pesawat terbang yang diprediksi akan mendarat di Bandara Juanda dapat dilihat pada Tabel 9.

Tabel 9. Prediksi Aircraft Classification Number (ACN) di Bandara Juanda

\begin{tabular}{|c|c|c|c|c|c|c|c|}
\hline \multirow{2}{*}{ No. } & \multirow{2}{*}{ Jenis Peswat } & \multirow{2}{*}{$\begin{array}{l}\text { Maximum Take Off Weight, MTOW } \\
\text { (Kg), utk Panjang Landas Pacu 3000m }\end{array}$} & \multirow{2}{*}{$\begin{array}{c}\text { Bahan Bakar utk } \\
\text { Taxiing (Kg) }\end{array}$} & \multirow{2}{*}{$\begin{array}{c}\text { Gross Weight } \\
(\mathrm{kg})\end{array}$} & \multicolumn{3}{|c|}{ CBR Subgrade } \\
\hline & & & & & $15 \%$ & $10 \%$ & $6 \%$ \\
\hline 1 & A340-200 & 275,000 & 900 & 275,900 & 52 & 60 & 72 \\
\hline 2 & A340-300 & 271,000 & 900 & 271,900 & 55 & 60 & 70 \\
\hline 3 & A340-500 & 360,000 & 1200 & 361,200 & 59 & 67 & 80 \\
\hline 4 & A340-600 & 360,000 & 1200 & 361,200 & 59 & 67 & 80 \\
\hline 5 & B747-8 & 438,000 & 1360 & 439,360 & 62 & 68 & 86 \\
\hline 6 & B767-300ER & 182,000 & 454 & 182,454 & 48 & 54 & 63 \\
\hline 7 & B767-400ER & 202,000 & 454 & 202,454 & 55 & 61 & 75 \\
\hline 8 & B777-300ER & 280,000 & 910 & 280,910 & 46 & 51 & 62 \\
\hline
\end{tabular}

\section{Kesimpulan}

Berdasarkan hasil analisa dan pembahasan, maka dapat disimpulkan hasil evaluasi terhadap kekuatan perkerasan landas ancang sisi selatan landas pacu bandara Juanda adalah sebagai berikut:

(a) Struktur perkerasan landas ancang eksisting adalah sebaagai berikut:

a. Lapisan overlay, yang berupa, meterial beraspal dengan tebal $60 \mathrm{~mm}(=2,36 \mathrm{inch})$

b. Surface course lama, terdiri dari lapisan asphaltic concrete wearing course (AC-WC), yaitu lapisan pertama setebal $540 \mathrm{~mm}(=21,26$ inch $)$.

c. Base course, terdiri dari agregat base dengan tebal $500 \mathrm{~mm}(19,69$ inch).

d. Subgrade, yang terdiri dari material batu karang.

(b) Prediksi pergerakan tahunan pesawat terbang yang melewati landas ancang sisi selatan landas pacu bandara Juanda adalah sebgai berikut: A-320 sebanyak 9932 pergerakan, A-330 sebanyak 416 pergerakan, A-332 sebanyak 52 pergerakan, A-333 sebanyak 52 pergerakan, B-738 sebanyak 10088 pergerakan, B-747 sebanyak 364 pergerakan, B-772 sebanyak 208 pergerakan, B-773 sebanyak 520 pergerakan, CRJ sebanyak 468 pergerakan.

(c) Untuk semua skenario analisis PCN dan ACN menunjukkan tidak memerlukan lapis ulang kecuali untuk skenario asumsi CBR 6\% dimana PCN B777-300ER berdasarkan metode Comulative Damage Factor (CDF) yakni 80, lebih kecil dibanding ACN pesawat terbang B777-300ER pada maximum gross weight yakni 89.

\section{Saran}

Adapun saran yang diberikan oleh penulis adalah sebagai berikut:

(a) Penyempurnaan program bantu untuk analisis ekivalen tebal perkerasan Metode FAA

(b) Agar landas ancang sebelah selatan landas pacu bandara Juanda mampu dilewati pesawat terbang B777-300ER, maka perlu pembatasan gross weight, dimana pembatasan tersebut akan berakibat pada pembatasan rute pelayanan dari dank ke bandara Juanda. 


\section{References}

Use the "Insert Citation" button to add citations to this document.

[1] _ Data Pergerakan Pesawat Bandara Juanda, PT. Angkasa Pura I (Persero), 2013.

[2] Laporan Penelitian Evaluasi Kekuatan Struktural Perkerasan Parallel Taxiway Selatan Bandara Juanda Surabaya, PT. Angkasa Pura I (Persero), 2013.

[3] __ Airport Design Software, http://www.faa.gov/airports/engineering/design_software/, 2014. 